\title{
The Achievements and Limitations of Statutory and Non-statutory Tripartism in South African Mining
}

\author{
May Hermanus, Sizwe Phakathi, Nancy Coulson and Paul Stewart
}

\begin{abstract}
Unresolved problems in South African mining, particularly on gold mines, are enmeshed within the system of production through mining methods and labour practices entrenched by apartheid. This system sets the parameters for, and hence limits and constrains, strategies designed to improve occupational health and safety. This chapter explores the achievements and limitations of statutory tripartism in mining as practiced under the Mine Health and Safety Act (MHSA), in the context of social dialogue in the National Economic and Labour Council (NEDLAC) and other statutory and non-statutory tripartite forums. The term statutory tripartism refers to the institutions and forums for social dialogue established in law. Non-statutory tripartism refers to ad hoc forums in which stakeholders deliberate on specific issues. Presented as a detailed case study in which issues are explored thematically, the chapter benefits from the experience of the lead authors in statutory mine health and safety structures. The authors reflect on the International Labour Organization's (ILO) role to date and its future role, at a time when prospects for a broad social compact remain out of reach. While key discussions often take place outside of formally established tripartite structures, the ILO's vision of authoritative social compacts and its institutional forms find expression in many settings. The ILO was important at critical junctures in the past and a continued role in championing social protection, inclusion and dialogue is foreseen. South Africans themselves must, however, find agreement on how best to address systemic issues. The practice of tripartism remains relevant to creating an inclusive and more equal society.
\end{abstract}

Introduction

South Africa was a founder member of the International Labour Organization (ILO). It was forced to withdraw from the Organization in 1964 having

(C) MAY HERMANUS ET AL. 2019 | DOI:10.1163/9789004399013_005

This is an open access chapter distributed under the terms of the prevailing CC-BY-NC license at the time of publication.

May Hermanus, Sizwe Phakathi, Nancy Coulson, and Paul Stewart - 9789004399013 
fallen foul of the Discrimination Convention of $195^{1}$ and rules against forced labour, under apartheid. The ILO's criticism of apartheid is set out in the 1964 Declaration on Action against Apartheid in South Africa. ${ }^{2}$ Throughout the 1970 s and 1980s the ILO continued to oppose apartheid, maintaining contact with employers representing international companies and mobilising support for South African trade unions and liberation movements (Grawitzky, 2013, 5). During the transition period, early to mid-199os, the ILO was central to securing resources and technical expertise for democratic trade unions and participants in tripartite forums charged with designing post-apartheid labour market policy and governance (Saul, 1993; Grawitzky, 2013). These deliberations were primarily overseen by the Department of Labour (DoL). South Africa re-joined the ILO on 26 May 1994.

The country's transition to democracy was in part due to powerful trade unions and organised business recognising their interdependence and the value of social dialogue (Webster and Sikwebu, 2010, 177). Major union federations, the Congress of South African Trade Unions (COSATU) and the National Council of Trade Unions (NACTU), who were militant opponents of apartheid and who represented black industrial workers, had by the 1980 s established a track record for forcing the apartheid government to consult them before changing labour laws (Gostner and Joffe, 1998, 131).

Contradictions in the labour law architecture under apartheid began to show in the late 196os because the economic implications of shortages of skilled labour had not been foreseen. Out of necessity, employers started training black workers, particularly Africans, for more skilled work. In time the apartheid government itself became concerned about giving all groups a stake in the system to ensure a common loyalty to the system and the country' (Kooy et al., 1979, 2). It appointed the Wiehahn Commission to look into the labour regime and labour legislation, and its recommendations were adopted in the period 1979-81. Thus, the previously racialised dual system of industrial relations characterised by relatively powerless company-level liaison committees that COSATU and the NACTU had actively opposed was abolished. Freedom of association was established and unions representing black workers then joined existing industrial councils (where the agreements struck between employers

1 See Convention no.11 - Concerning Discrimination in Respect of Employment and Occupation, 1958, http://www.ilo.org/wcmsp5/groups/public/@dgreports/@gender/documents/ genericdocument/wcms_114189.pdf (accessed on 5 June 2018).

2 Following a decision in 1963 by the ILO's Governing Body to exclude South Africa from various trade committees, the ILo Conference of June 1994 adopted the Declaration concerning the Policy of Apartheid of the Republic of South Africa in 1964, http://www.ilo.org/century/ history/iloandyou/WCMS_217915/lang--en/index.htm (accessed on 5 June 2018). 
and employees were legally binding). The Commission also established a dedicated court to adjudicate labour matters (Kooy et al., 1979, 11, 27; Dibben et al., 2015, 463). Interestingly, the Wiehahn Commission described South African labour relations at the time as 'tripartite' (Kooy et al. 1979, 3). The Commission marked a fundamental shift in industrial relations in South Africa and resulted in black workers intensifying their struggles for workplace and social rights (Lichtenstein, 2015; Bhorat et al., 2014, 4).

With the practice of bargaining and dialogue having started well before the transition to democracy, by the late 1980 s tripartism was accepted as a viable method for crafting social and labour policy. This gradual restructuring within the apartheid state and workplace was eventually institutionalised under the National Economic and Labour Council (NEDLAC), in 1994, both deepening democracy and 'channelling discontent' (Webster and Sikwebu, 2010, 176-177; Benjamin and Cooper, 2016, 3). The intention was to discuss all changes to labour, social and economic policy in NEDLAC before presentation to parliament. Labour-related matters such as basic conditions of employment, the ILO concept of decent work, workers' compensation, minimum wages, employment equity and youth unemployment were addressed by NEDLAC.

In South Africa, the DoL is the custodian of the country's relationship with the ILO. Most labour market institutions in South Africa are located in the DoL with the exception of those dealing with mine health and safety and with the education and training of mineworkers. The latter are located within the Department of Mineral Resources (DMR), formerly the Department of Minerals and Energy. The extended mandate of the mining department is a historical artefact arising from mining's central role in the industrialisation of the country and created room for differentiated approaches to tripartism. The tripartite Mine Health and Safety Act (MHSA) No. 29 of 1996 as amended came into effect two years after the establishment of NEDLAC.

As little social value was attached to black lives, mining operations were not designed for safety and health, from the outset and for most of the twentieth century. Employers in mining and elsewhere upheld apartheid in the workplace by coercive means (Phakathi, 2012). Production was optimised in the support of the 'politics of white supremacy' (Jeeves and Crush, 1995, 6) through migrant labour, low wages and little regard to the health and safety of miners. Work on mines was brutally policed until the mid-196os, when production incentives and a rational job-grading system were introduced (Moodie, 2005, $547,566)$. From the 1980 onwards, the mining sector's dismal health and safety record began to improve on the back of the unionisation and mobilisation of black mineworkers by the National Union of Mineworkers (NUM). In 1994, NUM succeeded in securing a 'Commission of Inquiry into Safety and Health in 
the Mining Industry', leading to the enactment of the M HSA in 1996 two years into democracy. The MHSA, which developed alongside the ILO's Convention 176 (ILO, 1995), gave rise to the tripartite Mine Health and Safety Council (MHSC) and the Mining Qualification Authority (MQA). The rights, procedures and arrangements established by the MHSA mirror those of Convention 176 . The practice of social dialogue and associated institutional innovations of the new national labour regime were thus also reflected in the MHSA, which represents the first formal application of tripartite principles in mining in democratic South Africa. Through the MHSA, for the first time in South African history, mineworkers and their representatives could influence decisions affecting their working conditions. By that point, a racialised and discriminatory system of labour-intensive mining had prevailed for almost a century.

\section{2 The Practice of Tripartism in Democratic South Africa}

\section{1}

\section{Statutory Tripartism: The National Economic and Labour Council (NEDLAC)}

The NEDLAC Act of 1994 (NEDLAC, 1994) adapted the concept of tripartism to include the voices of poor and marginalised South Africans. The Act recognised four stakeholder groups-government, organised business, organised labour and 'community' (representatives of civil society)—rather than three. New laws on labour relations, conditions of employment and skills development followed the establishment of NEDLAC (Benjamin and Cooper, 2016, 3). But the implementation of these new laws and policies fell short of expectations (Bezuidenhout et al., 2008, 64-68; von Holdt and Webster, 2005, 21). This diminished prospects for a broad social compact premised on agreed macroeconomic policy, designed to achieve substantive economic upliftment, economic growth and participation in the formal economy by black South Africans.

The advent of democracy and the institutionalisation of tripartism coincided with the rise of globalisation. Alongside the structural problems in the national economy, changes in the global economy also raised formidable barriers to NEDLAC's attempts to improve employment levels and increase participation in the formal economy. The casualisation of work, for example, compounded the problem of systemic unemployment caused by apartheid policies (Theron, 2005, 314; von Holdt and Webster, 2005, 30). In mining, the level of contracting was estimated at 28 per cent by 2012 (Deloitte, 2013, 2). Contract workers earned less than workers in permanent jobs and their living conditions were poorer and often informal. Casualisation increased job insecurity 
and created difficulties in maintaining fair labour practices and standards. These were contributing factors to the explosive situation at Marikana Platinum Mine, culminating in 2012 in the deaths of 34 striking miners and the injuring of 78 others under fire from the South African Police (Farlam et al., 2015, 514, 544-559; Deloitte, 2013, 4). Globalisation also created opportunities that benefitted large South African mining companies rather than the local mining industry, and these companies moved their head offices and stock exchange listings offshore as they internationalised their portfolios. Within the country, private sector investments in mining research and development dropped off since it appeared that expertise could be sourced from anywhere in the world.

NEDLAC's capacity to foster deep societal change was also hampered by internal difficulties. Employer organisations and unions represented in NEDLAC were not broadly representative of society. Despite widespread unionisation, large numbers of South African workers were not unionised, and the interests of smaller and large employers diverged (Dibben et al., 2015, 465). As new opportunities became available to black South Africans thanks to democratisation, trade unions' capacity to effectively represent workers diminished, with the loss of senior trade unionists to positions in government and business and promotions into supervisory and management positions at work (Buhlungu, 2010, 157-166; Hirschsohn, 2011). Even the 'community' group was not fully representative of civil society. Many civil organisations failed to meet NEDLAC's membership criteria, and the community group's participation in NEDLAC was limited to discussions on development (Webster and Sikwebu, 2010, 181-184, 214). It was apparent within a few years that dialogue in NEDLAC was more adversarial than consensus seeking. Few agreements were struck, raising questions about NEDLAC's capacity to deliver on its mandate (ka'Nkosi, 1997). This led to the creation of the controversial Millennium Labour Council in 2000 to augment NEDLAC, in which disagreements were to be hammered out before reaching NEDLAC (Dibben et al., 2015, 466). After the events at Marikana in 2012, a review of NEDLAC was commissioned in the face of continued concerns over whether it could deliver a viable social compact (Joffe, 2013). The ILO provided support for this review. To date, no alternatives to NEDLAC have emerged and efforts continue to address its shortcoming and limitations. As reviewers Webster and Joynt pointed out, NED LAC could be fixed. The foremost challenge was to overcome the insider-outsider problems in which in big business, 'a labour aristocracy' and a highly paid civil service seek to maintain the status quo (Webster and Joynt, 2014) rather than make fundamental compromises. 


\subsection{Non-statutory Tripartism in Mining and the Role of 'Summits'}

Prior to the establishment of the MHSA in 1990, NUM called for social dialogue and tripartite discussion over the economic future of the mining industry. While the first of these 'mining summits' failed, the NUM put forward a demand for an inquiry into mine health and safety, which eventually resulted in the appointment of the Commission that recommended the MHSA (Masilo and Rautenbach, 2008, 1-2). After the M HSA was enacted in 1996, from 1998 onwards several mining summits, and initiatives such as Deep Mine, PlatMine and FutureMine, were convened to address issues in gold- and platinum-mining (Durrheim, 2007). These endeavours were collaborative, multi-stakeholder and tripartite in form, and included scientific research. The common thread was to stave off mine closures and prevent job losses. In coal-mining, the CoalTech Research Association, established in 1999, is another example of a multiparty forum in which government, labour and employers are represented, in this case to secure the future of the coal sector by focussing on sustainability, competitiveness and safety (CoalTech, n.d.). Except for CoalTech, these initiatives had limited success as they failed to translate into concrete, ongoing programmes of work.

Cracks became evident in the ad hoc tripartite practices associated with the DMR when the Mining Industry Growth, Development and Employment Task Team (MIGDETT), established in December 2008 by agreement between the tripartite stakeholders, did not conclude its work. MIGDETT was created in response to the global economic and financial crisis, which particularly affected the mining sector. It was to develop strategies for transforming the industry through interventions to improve competitiveness, increase the participation of black South Africans in mining, minimise job losses and position the mining industry for sustainable growth (PMG, 2010). The 2017 Revised Mining Charter (DMR, 2017), developed by the DMR, dealt with the issues assigned to MIGDETT. Serious differences (le Cordeur, 2017) over the appropriateness and viability of the policies and mechanisms proposed in the Charter led to organised business and government turning to the courts for resolution.

The Mining Phakisa ('phakisa' means 'hurry up') is a recent and more hopeful expanded tripartite initiative than MIGDETT. It got underway in 2015 without significant involvement from the DMR. The Phakisa adopted a holistic approach to replacing outdated technologies, processes and organisational structures on gold and platinum mines. It recognised the interdependence of the futures of gold- and platinum-mining, and the many people, communities and industries dependent on these commodities. It also revisited the linkages between mining and industrial development. One of the workstreams of 
the Phakisa envisaged a mechanised and ultimately automated, low-profile mining system which was to be designed and produced locally. This system would address the challenges in mining, create new employment opportunities, and meet local and international demand for such systems. A similar idea had been set aside in the past because of the depth of mining, the uniqueness of the gold and platinum ore-bodies, worker resistance, and managerial conservatism (Paul Stewart, 2015). Following protracted discussions within and between the private and public sectors, and herculean efforts to raise the necessary funding, the first phase of research and development work finally started in late 2016 (CSIR, 2016). The background to and practice of social dialogue and tripartism in mining, both non-statutory and statutory, is summarised in Figure 4.1.

PRE-DEMOCRACY - A rrangements and conditions

Labour-intensive mining starts in 1868 (diamonds) and 1886 (gold)

1902: The Witwatersrand Native Labour Association (WNLA) established to recruit black workers as migrants

1979: Unions representing black workers allowed into industrial councils

1987: Mining jobs peak

199o: NUM calls for tripartite discussions on the economic future of the mining sector and demands inquiry into mine health and safety

Pre 1994: Engagement between government, employers and labour entrenched

\section{4 - Start of democractic era}

STATUTORY TRIPARTISM

1994: National Economic and Labour Council (NEDLAC)

established

1994: Commission of Inquiry into Safety and Health in Mining Industry starts

1996: Mine Health and Safety Act promulgated

- Tripartite Mine Health and Safety Council established

- Mining Qualifications Authority established
The mining summits

ADHOC TRIPARTITE-LIKE INITIATIVES

1998-20o2: Collaborative Deep Mine programme for safe, efficient and profitable gold-mining

1999: CoalTech 2020 Research

Association for safe and sustai

nable coal-mining

2003-06: FutureMine programme for improved mining technology

2006-og: PlatMine - Collabo rative Research Programme for safer mining and the transition to mechanised mining

2008 onwards: Mining Industry Growth, Development and Employment Task Team (MIGDETT)

2016: Mining Phakisa. Future of Mining (gold and platinum)

FIGURE 4.1 Practice of social dialogue and tripartism in mining SOURCES: BAARTJIES ET AL., 2007; BENJAMIN AND COOPER, 2016; COALTECH, N.D.; COMSA, N.D.; COMSA, 2017; COMSA, 2010-17; COMSA, 2005-17; CSIR, 2016; DURRHEIM, 2007; LEON ET AL., 1994; MASILO AND RAUTENBACH, 2008, 1-2; MCCULLOCH, 2012, 9-10; PMG, 2010; WEBSTER AND JOYNT, 2014. 


\subsection{Statutory Tripartite Structures of the MHSA: Achievements and Limitations}

The provisions of the MHSA mark South Africa's first legislated application of tripartite principles in mining. The MHSA sets out specific responsibilities for government, employers and workers' representatives. These parties are required to work together to ensure mineworkers' health and safety. The government's responsibility for mine health and safety resides with Mine Health and Safety Inspectorate (MHSI) in the DMR. The MHSI is responsible for health and safety at mines and for the effects of mining on people in surrounding settlements and communities. The M HSA also gave rise to the tripartite MHSC and the Mining Qualifications Authority (MQA). In law, the Chief Inspector of Mines chairs both the MHSC and the MQA.

Under the MHSA, the M HSC was designed to address the extremely high levels of death and injury among mainly black mineworkers. The MHSI is the single representative of government in the Council. Employers are primarily represented by the South African Chamber of Mines (COMSA). The South African Mining Development Association (SAMDA), representing mainly black-owned small and medium-sized mining companies, is largely inactive. The multiplicity of unions representing workers is indicative of the divisions among and stratification of the workforce. The main fault lines are skill levels and race, and more recently rivalry and competition between the NUM and the Association of Mine Workers and Construction Union (AMCU). The NUM and AMCU largely represent black mineworkers, while the other unions-Solidarity and the United Association South Africa (UASA) - represent artisans, technicians and supervisory staff, that is to say, workers in occupations historically reserved for 'whites'. AMCU emerged in 2012 as a militant union in direct challenge to the NUM and just over a year ago agreed to formally participate in the MHSC. The unions representing mineworkers are increasingly more general than sector specific.

\subsubsection{The Mine Health and Safety Council}

Many achievements are associated with the M HSC and its subcommittees, including the development of regulations and guidelines, the publication of a widely respected handbook on occupational health (Guild et al., 2001), several guidebooks and research programmes. In addition, since the inception of the M HSA several national tripartite initiatives have been launched (Table 4.1).

The MHSA introduced rights for workers - to representation, participation, information and training and the right to refuse dangerous work. Under the MHSA an extensive body of related law was developed over time, which included codes of practice (both mandatory and offering guidance) that invoke 
Tripartite initiatives

12003 to 2013 , Safety Milestones (Journey towards Zero Harm).

Main thrusts were to reduce fatalities to sector-leading levels, ${ }^{\text {a }}$ eliminate silicosis and eliminate noise-induced hearing loss.

2 milestones, and the formation of Regional Tripartite Health and Safety Forums.

3 2oog, Mining Occupational Health and Safety (MOSH) Learning Hub established.

42011 , Culture Transformation Framework developed and approved.

52014 , Milestones on Health and Safety.

2016, Signed pledge by tripartite stakeholders to ensure achievement of occupational health and safety milestones.

\section{Lead institution}

Mine Health and Safety

Council

Mine Health and Safety

Council

Chamber of Mines of

South Africa

Mine Health and Safety

Council

Mine Health and Safety

Council

Mine Health and Safety

Council

a South African mining fatality rates were benchmarked against the averages of the fatality rates of the mining sectors of Canada, the USA and Australia.

SOURCES: COMSA, 2005-17; MHSC, 2016; MHSC, 2014; MOSH, NO DATE.

the MSHA's principal concepts-tripartism and risk management. To date, 23 new regulations have been introduced, along with 12 guidelines for mandatory codes of practice and further informal guidance notes.

At mine sites, the MHSA requires engagement between inspectors from the MHSI, employers' and employees' representatives, and bipartite engagement between employers' and employees' representatives. The latter has resulted in:

- Company and mine-level agreements on arrangements for information sharing, joint planning and decision-making, training and auditing.

- Health and safety committees at every mine or on every shaft (the latter in the case of large mines).

- Mineworker health and safety representatives or stewards, who are members of health and safety committees or subcommittees.

The committees consider issues raised by workers, managerial concerns, levels of compliance to rules and standards, training, health and safety interventions, 
and incident investigations and their results. A sector-wide audit of these requirements (which included small-scale mines) conducted by the MHSI in 2008 found that two-thirds of mines comply with these arrangements (DME, 2008).

\subsubsection{Mixed Results for Mine Safety}

Mining employment peaked at over 827,000 employed in 1987, with just over 564,000 ( 67 per cent) working on gold mines; but thereafter gold-mining employment declined almost steadily to 115,822 people in 2016 (Nattrass, 1995, 862; Seekings and Nattrass, 2002, 5-6; Baartjies et al., 2007, 3-4; COMSA, $2017,9)$. Higher levels of employment in platinum-, coal-, iron-, chrome- and manganese-mining have not offset the job losses in gold-mining, losses that were due to lower gold prices, the declining quality of gold reserves and increasing costs and difficulties in extracting gold at deep levels using labour-intensive methods (Nattrass, 1995, 865). Sharp declines in employment followed. Given the structural linkages between the mining sector and local industry, the contraction of the mining sector affected employment levels across the economy (Fine, 2008; Fine and Rustomjee, 1996).

At face value there have been huge gains for health and safety. The Commission of Inquiry into Mine Health and Safety documented that between 1900 and 1993 over 69,00o mineworkers lost their lives, and that over 1,000,00o were seriously injured (Leon et al., 1994, 15). In 1993, gold-mining fatalities accounted for 418 of the 578 fatalities recorded, while in coal-mining - then ranked the second most dangerous mining environment after gold - 90 deaths were recorded (Leon et al., 1994, 19). By 2016 the number of deaths per annum due to mine accidents had fallen by 88 per cent to 73 in total, with the majority recorded on gold, platinum and coal mines, respectively (M HSC, 2016, 20). This change is significant by South African standards.

The major causes of death and injury among mineworkers involve 'falls of ground' (FoG) from the roof and sidewalls of the workplaces in underground mines, transport in mining, and machinery. These have been the focus of preventative interventions (M HSC, 2016, 37; COMSA, 2017, 3-4) under the health and safety milestones agreed by the MHSC and referred to in Table 4.1. The mining sector has also been prone to disasters associated with rockbursts in deep-level mines, flammable gas explosions in coal and gassy gold mines, mine fires, and shaft-related accidents in deep-level gold mines. Disasters have decreased from a high of 82 in the 1990s to four in the period 2010-14, through better understanding and avoidance of the conditions and mechanisms that precipitate them. From 2003 onwards, the number of lives lost on gold mines became more comparable to those lost in platinum- and coal-mining (M HSC, 
2014, 20), significantly reducing overall fatality frequency rates and the number of fatalities in mining. This is due to the falling numbers of people employed in gold-mining (COMSA, 2017, 9), and to rising employment (albeit not matching gold-mining job losses) at mines on which hazards are more amenable to control, such as mines at which trackless and mechanised mining methods are in use. The DMR currently only reports numbers of fatalities for the sector and each commodity, and not the associated fatality rates, which are indicative of the level of risk per year and are calculated as the number of fatalities per 200,000 or 1,000,000 hours worked.

While health and safety interventions have undoubtedly brought about improvement on all mines, the contraction of gold-mining has had a significant effect on reducing mortality. Figure 4.2 shows the relationship between trends in fatality rates (the number of fatalities per million hours worked) on gold mines and the mining industry overall, as well as employment trends. While overall levels of employment ranged between 400,000 and 500,000 people employed for nearly two decades and employment in gold-mining has fallen dramatically, the annualised fatality rates for the sector still strongly correlate to that of gold-mining. The linear correlation coefficients between the goldmining fatality rate and the overall mining fatality rate are 0.98 for the period

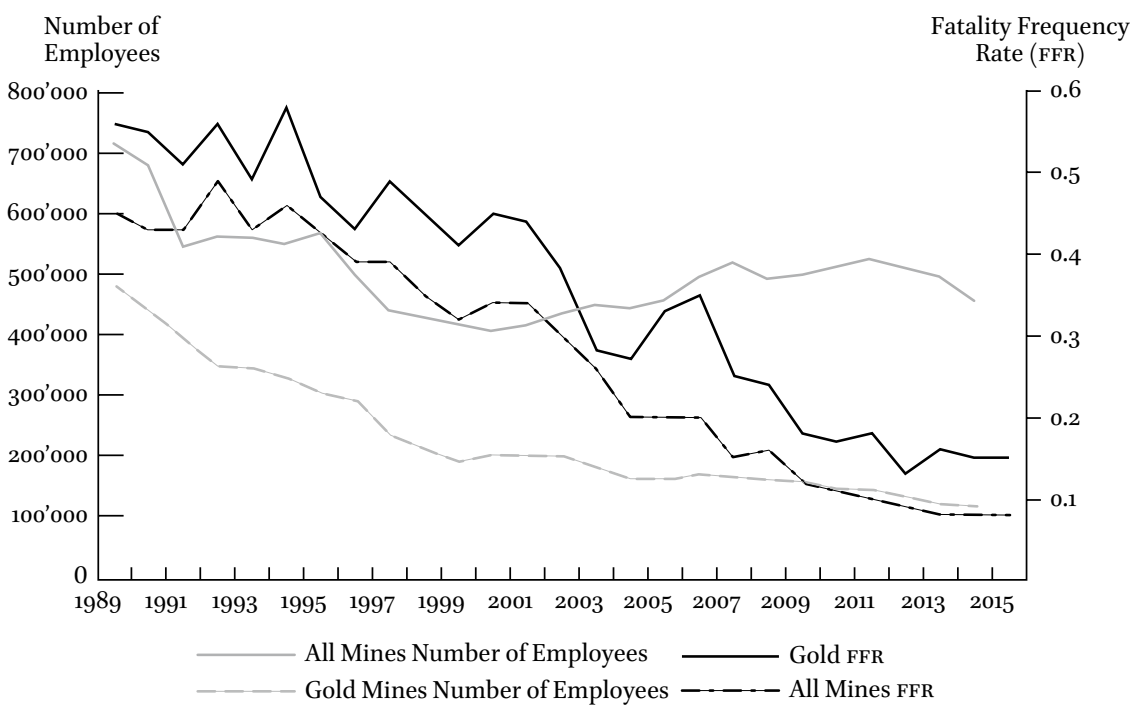

FIGURE 4.2 Gold-mining employment and fatality rates (number of fatalities per million hours worked) vs. industry employment and fatality rates SOURCES: BAARTJIES ET AL., 2007; COMSA, 2017; COMSA, 2010-17; COMSA, 2005-17; MHSC, 2016; MHSC, 2014. 
1990-2015 and 0.92 for the period 2003-16 (when the health and safety milestones applied). This is indicative of how developments in gold-mining influence the level of risk in the sector. The key factor has been the closure of older, difficult to operate and hazardous mines and sections of mines. Consequently, the level of improvement suggested by safety data cannot solely be ascribed to improvements in safety per se, as the effect of the shrinking gold sector has been significant.

Outside of the formal mining sector, the number of deaths among informal miners who work in 'closed' or officially decommissioned mines, mainly gold but also coal mines, has risen steeply. These deaths are not yet included in the official statistics. The contexts in which these deaths occur are conflicts between different groups of informal and technically illegal miners, increased environmental damage caused on land already affected by mining, health risks, and child labour. In South Africa, the working of decommissioned mines is illegal. The miners are often destitute ex-mineworkers and many appear to have been recruited by crime syndicates. Fires and rock falls in decommissioned mines are the main reported causes of death among informal miners, and their full extent is unknown. In March 2017, the bodies of 14 informal miners were found in a small town east of Johannesburg and their deaths were ascribed to rivalry among competing groups of miners (Pijoos, 2017). In 2009, 61 miners were estimated to have died in a mine fire (Mail \& Guardian Online Reporter and SAPA, 2009), and in May 2017, 40 people were reported dead following an 'illegal mining' related explosion (Hosken, 2017).

\subsubsection{Occupational Health: Significant Legacy Issues}

Improving occupational health remains a serious challenge. The reliability of occupational disease data is a worldwide problem. Reasons for this include long periods of latency before disease becomes evident, difficulties in recognising occupational disease outside of the workplace and inadequacies in the systems for diagnosing, documenting and recording occupational diseases (Burgard and Chen, 2014, 148). These factors are compounded in South Africa by systemic indifference to the well-being of mineworkers and by the manifestation of occupational disease long after miners have returned home to far off rural areas. The Commission of Inquiry into Mine Health and Safety concluded on the basis of various studies that rates of conditions such as tuberculosis (TB), noise-induced hearing loss, silicosis and coal miners' pneumoconiosis were very high, and possibly at epidemic levels (Leon et al., 1994, 17). Further evidence emerged after the Commission had completed its work, of several epidemics of occupational lung diseases affecting asbestos miners and their communities and gold miners exposed to silica dust (Felix et al., 1994; McCulloch, 
2009; Murray et al., 2011). Current data gathered by the DMR suggest that exposure levels to airborne dusts have been reduced, but the effects thereof on levels of occupational disease are not yet apparent.

Efforts to improve occupational health are, as with safety, guided by the milestones set at the MHSC. The priorities are to reduce noise in mines, improve the effectiveness of hearing-conservation programmes, reduce exposure to airborne pollutants through improved ventilation systems, and introduce measures to prevent dust from becoming airborne (MHSC, 2016, 6, 9-10). Data from the DMR show that the number of cases of occupational diseases diagnosed declined between 2003 and 2013, the period to which the first set of health and safety milestones applied. This trend corresponds to declining numbers of cases reported at gold mines. While 7,461, 2,042 and 5,783 cases of pulmonary tuberculosis, silicosis, and noise-induced hearing loss, respectively, were diagnosed in 2003, by 2013 these numbers declined to 1,900, 1,164 and 471, respectively (MHSC, 2014, 20). As shown in Figure 4.3, the entire sector's occupational health data track that of gold-mining, with particularly close correlations between the number of recorded cases of silicosis and TB in the whole sector and the number of cases recorded on gold mines.

Compensation owed to ex-mineworkers suffering from occupational disease has not been successfully addressed through statutory tripartism and

Incidence of

Occupational Disease

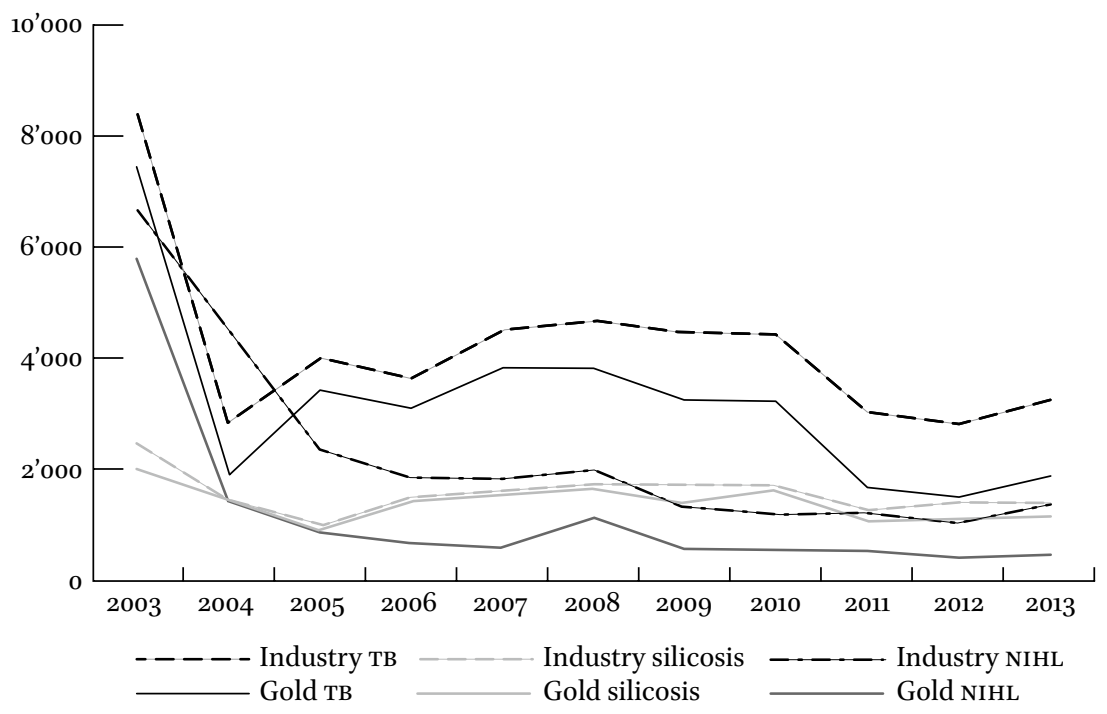

FIGURE 4.3 Occupational health: mining sector relative to gold-mining SOURCES: BAARTJIES ET AL., 2007; COMSA, 2010-17; MHSC, 2016; MHSC, 2014. 
continues to weigh heavily on the sector. In 2003, litigation against Cape plc resulted in a settlement in favour of asbestos miners and mining communities, 'the award of which was managed by the Asbestos Relief and the Kgalagadi Relief trusts' (Asbestos Relief Trust, 2003). In 2016, litigation to secure compensation for 4,365 claimants for silicosis and silico-tuberculosis contracted in gold mines resulted in a settlement of USD 35 million (ZAR 464 million) with Anglo American SA and AngloGold Ashanti. This settlement followed 12 years of litigation and may pave the way for an industry-wide compensation scheme for all gold miners with silicosis (Meeran and Martin, 2016). A separate silicosis class action lawsuit, underway since 2012, aims to secure claims against 30 gold-mining companies (Bega, 2017). This claim could benefit over 200,00o miners and their families through a settlement reached on 3 May 2018 (Reuters, 2018a; Reuters, 2018b). These lawsuits point to one of the limitations of statutory tripartism - namely, that legacy issues have not been brought into statutory structures. Recent attempts to resolve compensation payment backlogs affecting tens of thousands of migrant ex-mineworkers are being facilitated through a partnership between the World Bank, the International Organisation for Migration and the Department of Health. While the MHSC hosted the 2016 Compensation Summit, it has not yet found a way to deliberate on one of the most poignant legacy issues in South African mining.

\subsection{Mixed Experience with Workers' Rights}

The health and safety rights of mineworkers were strengthened by the introduction of the MHSA. Studies show progress with respect to the practice of worker-elected health and safety representatives and with Section 23 of the MHSA, which gives workers the right to leave a dangerous workplace. In each case, however, workers have yet to fully realise their rights.

Case study research found that the activities of health and safety representatives included important health and safety tasks such as risk assessment, worker education and compliance, supervision of worker health and wellbeing, and administration and reporting. However, in each area of activity, health and safety representatives faced significant obstacles in the execution of these tasks and there were more risks than benefits to being a health and safety representative (Coulson, 2016).

A sector-wide study commissioned by the MHSC found that the provisions of Section 23 had been successfully communicated to mineworkers in the large gold, coal and platinum commodity sectors, and virtually all were aware of their rights and had had some training (albeit by their employer) on how to exercise them. However, there were shortcomings. Workers could not state the procedure associated with the right, mineworkers deferred to their health and 
safety representatives prior to taking any action, casual workers were less likely to exercise the right, and up to a third of workers who withdrew from their workplace returned there still thinking it was dangerous (Coulson et al., 2018).

The experience of worker-employer safety committees remains undocumented. It is thought that the emergence of AMCU in direct competition with the NUM may have reduced the effectiveness of these committees and the arrangements for worker representation. The underpinning collective agreements between recognised trade unions and the employer are premised on the presence of a majority union, and relations between AMCU and the NUM tend to be tense, adversarial and prone to violent confrontation (Chinguno, 2013).

\subsection{Divisions between Stakeholders Persist}

The sector-wide Mine Occupational Safety and Health (MOSH) Leading Practice Adoption System aimed to introduce, across the South African mining sector, technologies and procedures that have a demonstrable impact on health and safety performance. This comsa-led programme was found-despite its best efforts to involve other stakeholders - to, in practice, be expert-led and unable to target mines with the worst health and safety performance; statutory representative structures for workers were bypassed and the DMR was ambivalent about direct involvement (Hermanus et al., 2015). The initiative was conceived outside the MHSC although labour and the MHSI thought it ought to be brought under the Council's umbrella. Ultimately, involvement by the industry in MOSH was not left as voluntary and companies were required to report on their consideration and uptake of MOSH technologies under the Mining Charter II score card (a regulatory instrument that aims to 'transform' the mining sector).

In the last five years the DMR has adopted an increasingly punitive approach to enforcement in an effort to force improvement upon the industry. In terms of Section 54 of the MHSA, mine inspectors can stop a section of a mine, or an entire mine, when there is a serious and imminent threat to the safety of mineworkers. How the DMR and the industry differ on the interpretation of this section of the Act is further straining their relationship (Ryan, 2016). The DMR issued directives to stop mines for a wide range of infractions, some seemingly minor, and described these as evidence of inspectors' stronger approach to enforcement (DMR, 2012). According to industry executives, stoppages were often justified, but not on the scale required by the DMR - closing an entire mine for infractions confined to a single workplace or mining section (Ryan, 2016). A labour decision in favour of AngloGold Ashanti gave weight to this argument when a judge ruled that DMR inspectors unreasonably failed to issue a directive proportional to the harm or potential harm they intended 
to prevent, but instead unfairly issued a Section 54 work stoppage to a whole mining operation. This was described as an unreasonable act on the part of the DMR in a Labour Court judgement. ${ }^{3}$

\section{3}

\section{Conclusions}

Tripartism and social dialogue is well established in South Africa with a new labour market regime replete with institutions, new laws and entrenched processes. In this the ILO has played a crucial role by opposing apartheid, exposing the links between apartheid and forced labour, supporting liberation and the exiled trade union movements during apartheid, training the participants of tripartite forums and resourcing efforts to institutionalise social dialogue in the transition to democracy.

But dialogue in the premier institution, NEDLAC, has been too fractious and too narrow to bring about agreement on addressing the deeply structural causes of poverty, unemployment and marginalisation in South Africa. Concerns over the adequacy of representation, divisions between stakeholders, and powerful interests in maintaining the status quo are among the issues that hamper NEDLAC. But NEDLAC can be fixed by acknowledging these problems and through a willingness to work towards substantive change (Webster and Joynt, 2014; Webster et al., 2008). There are also opportunities for creating a more comprehensive and 'joined up' form of tripartism by making fully visible the social project confronting South Africa and facilitating the connection between and the amplification of initiatives that show promise. While sectoral issues may require dedicated attention, NEDLAC could be positioned to take stock of, coordinate and influence dialogue across the wide spectrum of settings in which social dialogue takes place. NEDLAC's predicament is indicative of the current challenges facing the ILO in an increasingly globalised but fragmented world. The organisation could create and disseminate knowledge on how social compacts - the ideal that underpins tripartism — can be built and sustained. Extending its presence and bringing its expertise to bear in a wider range of forums could be one way of accomplishing this.

Similar issues beset mining as beset NEDLAC. There are divisions among the key stakeholder groupings, and the tripartite structures responsible for mine health and safety have largely avoided discussion on the inherent limitations

3 Johannesburg Labour Court, J2459/16, AngloGold Ashanti Limited vs Mbonambi and Others, 4 November 2016, http://www.saflii.org/za/cases/ZALCJHB/2016/522.html (accessed on 5 June 2018). 
of labour-intensive deep-level mining, the emergence of informal (illegal) mining, and the epidemics of occupational disease. This has led to one-sided or narrowly defined efforts to improve conditions in mining, unlike the efforts of the latest mining summit - the Mining Phakisa — which aims to transform gold- and platinum-mining in their totality. However, while the low-key role of the DMR in the Phakisa initiative and the lack of recognition of the initiative in NEDLAC might shelter the Phakisa from the turmoil present in these institutions in the short term, in the long run the Phakisa is likely to falter if it cannot garner sufficient and wide-ranging support for its objectives.

\section{References}

Asbestos Relief Trust (2003) Asbestos Relief Trust. Kgalagadi Relief Trust, http:// asbestostrust.co.za (accessed on 25 June 2017).

Baartjies, N., A. Auchterlonie, P. Sorenson and R. Goode (2007) Mining Sector Employment Scenarios for South Africa to 2024 (Cape Town, Johannesburg and Pretoria: Human Sciences Research Council), http://www.hsrc.ac.za/en/research-data/ ktree-doc/13796 (accessed on 23 June 2017).

Bega, S. (2017) 'Silicosis Case One of Mind Over Matter, Says Attorney', IOL News, 18 March, http://www.iol.co.za/news/crime-courts/silicosis-case-one-of-mind-overmatter-says-attorney-824159o (accessed on 25 June 2017).

Benjamin, P. and C. Cooper (2016) South African Labour Law: A Twenty Year Assessment, R4D Working Paper 2016/6 (Berne: World Trade Institute, Swiss Programme on Global Issues for Development, University of Berne), http://www.cth.co.za/wpcontent/uploads/2016/og/South-African-Labour-Law-A-Twenty-Year-Review.pdf (accessed on 10 December 2016).

Bezuidenhout, A., C. Buhlungu, S. Bischoff and K. Lewins (2008) Tracking Progress on the Implementation and Impact of the Employment Equity Act Since its Inception, commissioned report of the Department of Labour of South Africa (Cape Town, Johannesburg and Pretoria: Human Sciences Research Council, Development Policy Research Unit, and the Sociology of Work Unit), http://www.labour.gov.za/DOL/documents/ research-documents/tracking-progress-on-the-implementation-and-impactof-the-employment-equity-act-since-its-inception (accessed on 26 June 2017).

Bhorat, H., K. Naidoo and D. Yu (2014) Trade Unions in an Emerging Economy. The Case of South Africa, DPRU Working Paper 201402 (Cape Town: Development Policy Research Unit, University of Cape Town), http://www.cilt.uct.ac.za/sites/default/files/ image_tool/images/36/DPRU\%2oWP201402.pdf (accessed on 27 June 2017).

Buhlungu, S. (2010) A Paradox of Victory (Scottsville: University of KwaZulu-Natal Press). 
Burgard, S. and P. Chen (2014) 'Challenges of Health Measurement in Studies of Health Disparities', Social Science and Medicine 106, pp. 143-150, DOI:10.1016/j. socscimed.2014.01.045.

Chinguno, C. (2013) 'Marikana: Fragmentation, Precariousness, Strike Violence and Solidarity', Review of African Political Economy, 40(138), pp. 639-646, DOI:10.108o/ 03056244.2013 .854062 .

CoalTech (n.d.) CoalTech Research Research Association NPC, http://www.coaltech .co.za (accessed on 27 June 2017).

COMSA (Chamber of Mines of South Africa) (no date) A Brief History. Chamber of Mines of South Africa, http://www.chamberofmines.org.za/about/history (accessed on 23 June 2017).

COMSA (2017) Safety in Mining Fact Sheet 2017 (Johannesburg: Minerals Council of South Africa, formerly the Chamber of Mines of South Africa), www .chamberofmines.org.za/industry-news/publications/fact-sheets/send $/ 3$-fact -sheet/383-safety-in-mining (accessed on 10 December 2016).

COMSA (2010-2017)Facts andFigures (Johannesburg: Minerals Council South Africaformerly the Chamber of Mines of South Africa), http://www.mineralscouncil.org .za/industry-news/publications/facts-and-figures (accessed on 10 December 2018).

COMSA (2005-2017) Annual Reports (Johanesburg: Mineral Council South Africaformally the Chamber of Mines of South Africa), http://www.mineralscouncil.org .za/industry-news/publications/annual-reports (accessed on 10 December 2016).

Coulson, N. (2016) In Our Own Voices. The Risk and Benefits of Being a Workplace Safety Representative on South African Mine, paper presented at Mine Safe 2016, Johannesburg, South Africa.

Coulson, N., P. Stewart and S. Saeed (2019) South African Mine Workers' Experience of the Right to Refuse Dangerous Work and the Constraints to Worker Self-regulation, in The Journal of the South African Institute of Mining and Metallurgy, 119(1), pp. 21-30, DOI: 10.17159/2411-9717/2019/v119n1a3.

CSIR (Council for Science and Industrial Research) (2016) CSIR Role in Advancing the Mining Cluster, press release, 10 June, https:/www.csir.co.za/csir-role-advancing -mining-cluster (accessed on 11 May 2018).

Deloitte (2013) Contract Mining in South Africa. Are Current Models Supporting Business Sustainability, report, http://deloitteblog.co.za/wp-content/uploads/2013/o8/ Contract-mining-in-South-Africa-Are-current-models-supporting-sustainability .pdf (accessed on 11 December 2016).

Dibben, P., G. Klerck and G. Wood (2015) 'The Ending of Southern Africa's Tripartite Dream: the Cases of South Africa, Namibia and Mozambique', Business History, 57 (3), pp. 461-483, DOI:10.1080/00076791.2014.983483.

DME (Department of Minerals and Energy) (2008) Presidential Mine Health and Safety Audit (Pretoria: Department of Minerals and Energy (now Department of 
Mineral Resources)), http://www.klasslooch.com/Presidential\%2oAudit\%2oReport .pdf (accessed on 23 June 2017).

DMR (Department of Mineral Resources) (2017) Reviewed Broad Based Black-Economic Empowerment Charter for the South African Mining and Minerals Industry 2016, Government Gazette, 15 June, pp. 1-52, https://cer.org.za/wp-content/uploads/2010/o8/ Draft-reviewed-Mining-Charter.pdf (accessed on 19 June 2017).

DMR (2012) 2012 Budget Vote Speech, presented in parliament in Cape Town by the MiniMineral Resources, https://cer.org.za/news/minister-shabangus-2012-budgetvote-speech-for-dmr-mprda-integrated-permitting-fracking-rehabilitation-andconsultation-with-communities (accessed on 23 June 2017).

Durrheim, R. (2007) 'The DeepMine and FutureMine Research ProgrammesKnowledge and Technology for Deep Gold Mining in South Africa', in Y. Potvin and R. Stacey (eds.) Challenges in Deep and High Stress Mining (Perth: Australian Centre for Geomechanics), pp. 133-141.

Farlam, I., P.Hemrajand B. Tokota (2015) Marikana CommissionofInquiry:Reporton Matters of Public, National, and International Concern Arising Out of the Tragic Incidents at the Lonmin Mine in Marikana in the North West Province (Cape Town: Parliamentary Monitoring Group), https://www.gov.za/sites/www.gov.za/files/marikana-report1.pdf (accessed on 23 June 2017).

Felix, M., J. Leger and R. Ehrlich (1994) 'Three Minerals, Three Epidemics. Asbestos Mining and Disease in South Africa', Advances in Modern Environmental Toxicology 22, pp. $265^{-286 .}$

Fine, B. (2008) The Minerals-Energy Complex is Dead: Long Live the MEC? (London: School of Oriental and African Studies), https://eprints.soas.ac.uk/5617/1/MineralEnergyComplex.pdf (accessed on 10 December 2016).

Fine, B. and Z. Rustomjee (1996) The Political Economy of South Africa. From MineralsEnergy Complex to Industrialisation (London: Hurst and Company).

Gostner, K. and A. Joffe (1998) 'Negotiating the Future: Labour's Role in NEDLAC', Law, Democracy and Development 2(1), pp. 131-151, https://www.ajol.info/index.php/ldd/ article/view/138022/127592 (accessed on 14 December 2016).

Grawitzky, R. (2013) The Role of the ILO During and Ending Apartheid, International Labour Organisation meeting document (Geneva: ILO), http://www.ilo.org/ wcmsp5/groups/public/---africa/documents/meetingdocument/wcms_214906.pdf (accessed on 7 February 2018).

Guild, R., R. Ehrlich, J. Johnston and M. Ross (2001) SIMRAC Handbook of Occupational Health Practice in the South African Mining Industry (Johannesburg: The Safety In Mines Research Advisory Committeee).

Hermanus, M., N. Coulson and N. Pillay (2015) 'Mine Occupational Safety and Health Leading Practice Adoption System (MOSH) Examined - the Promise and Pitfalls of this Employer-led Initiative to Improve Health and Safety in South African Mines', 
Journal of the South African Insititute of Mining and Metallurgy, 115(8), pp. 717-727. DOI: 10.17159/2411-9717/2015/v115n8a8.

Hirschsohn, P. (2011) 'The "Hollowing Out" of Trade Union Democracy in COSATU? Members, Shop Stewards and the South African Communist Party', Law Democracy and Development, 15, pp. 1-31, DOI: http://dx.doi.org/10.4314/ldd.v15i1.6.

Hosken, G. (2017) 'Four Brothers Among 40 Dead in Illegal Mining Blast that Shook a Town', Business Live and Rand Daily Mail, 19 May, https://www.businesslive.co.za/ rdm/business/2017-05-19-four-brothers-among-40-dead-in-illegal-mining-blastthat-shook-a-town/ (accessed on1o June 2017).

ILO (International Labour Organization) (1995) C176-Safety in Mines Convention, 1995, No. 176 (Geneva: ILO), http://www.ilo.org/dyn/normlex/en/f?p=NORMLEXPUB: 12100:0::NO:12100:P12100_ILO_CODE:C176 (accessed on 10 December 2016).

Jeeves, A. and J. Crush (1995) 'The Failure of Stabilisation Experiments on South African Gold Mines', in J. Crush and W. James (eds.) Crossing Boundaries. Mine Migrancy in a Democratic South Africa (Cape Town: IDASA Publishing), pp. 2-13.

Joffe, H. (2013) 'Whither NEDLAC? Try Harder, Change it or Chuck it?', Business Day BusinessLive, 29 October, https://www.businesslive.co.za/bd/opinion/ columnists/2013-10-29-whither-nedlac-try-harder-change-it-or-chuck-it/ (accessed on 4 November 2017).

ka'Nkosi, S. (1997) 'Nedlac Fights Labour Critics', Mail and Guardian, 12 September, https://mg.co.za/article/1997-o9-12-nedlac-fights-labour-critics (accessed on 4 November 2017).

Kooy, A., D. Horner, P. Green and S. Miller (1979) The Wiehahn Commission: A Summary, SALDRU Working Paper No. 24 (Cape Town: Southern Africa Labour and Development Unit, University of Cape Town), http://opensaldru.uct.ac.za/bitstream/ handle/1109o/585/1979_kooy_swp24.pdf?sequence=1 (accessed on 25 Jun 2017).

le Cordeur, M. (2017) 'ANC to Meet Chamber of Mines, as Fitch Slams Mining Charter', Fin24 and City Press, 20 June, https://www.fin24.com/Economy/anc-to-meet-chamberof-mines-as-fitch-slams-mining-charter-20170620 (accessed on 25 June 2017).

Leon, R., M. Salamon, A. Davies and J. Davies (1994) Commission of Inquiry into Mine Health and Safety, Vol 1 , legal report (Pretoria: Department of Minerals and Energy).

Lichtenstein, A. (2015) 'A Measure of Democracy: Works Committees, Black Workers and Industrial Citizenship in South Africa, 1973-1979', South African Historical Journal, 67(2), pp. 113-138, DOI:10.1080/02582473.2015.1040061.

Mail and Guardian Online Reporter and SAPA (2009) 'Deadly Accident Puts Illegal Mining Under the Spotlight', Mail and Guardian, 2 June, https://mg.co.za/article/20o9o6-02-deadly-accident-throws-illegal-mining-under-spotlight (accessed on 25 June 2017).

Masilo, P. and G. Rautenbach (2008) Commentary on the Mine Health and Safety Act and Regulations (Cape Town: Juta and Co. Ltd). 
McCulloch, J. (2012) South Africa's Gold Mines and the Politics of Silicosis (Johannesburg: Jacana Media).

McCulloch, J. (2009) 'Counting the Cost: Gold Mining and Occupational Disease in Contemporary South Africa', African Affairs 108(431), pp. 221-240, DOI:10.1093/afraf/ adno85.

Meeran, R. and S. Martin (2016) 'Miners' Silicosis Win Paves Way for Industry Compensation Scheme', Mail and Guardian, 11 March, https://mg.co.za/article/2016 -03-10-miners-silicosis-case-win-paves-way-for-industry-compensation-scheme (accessed on 23 June 2017).

MHSA (Mine Health and Safety Act) (1996) The Mine Health and Safety Act, Government Gazette 29 (G17242) (Pretoria: Government Printing Works), http://www.wylie .co.za/wp-content/uploads/MINE-HEALTH-AND-SAFETY-ACT-NO.-29-OF-1996 .pdf (accessed on 10 December 2016).

MHSC (Mine Health and Safety Council) (2016) 2014 Summit Milestones Journey to Zero Harm. Occupational Health and Safety Statistics (Johannesburg: Mine Health and Safety Council), www.mhsc.org.za/sites/default/files/Mr\%2oMbonambi\% 2oMHSC\%2oSummit\%2oPresentation.pptx (accessed on 10 December 2016).

MHSC (2014) The Road to Zero Harm. Performance Review Against 2003 Milestones, (Johannesburg: Mine Health and Safety Council), http://www.mhsc.org.za/sites/ default/files/Mr\%2oMsiza\%2oPerfomance\%2oReview\%2oAgainst\%2oThe\% 202003\%20Milestone.pdf (accessed on 10 February 2015).

Moodie, D. (2005) 'Maximum Average Violence: Underground Assaults on the South African Gold Mines, 1913-1965', Journal of Southern Africa Studies 31(3), pp. 547-561, DOI:10.1080/0305707052000345090.

MOSH (Mining Industry Occupational Safety and Health) (no date) About Us, http:// www.mosh.co.za/about-us/about-mosh (accessed on 10 December 2016).

Murray, J., T. Davies and D. Rees (2011) 'Occupational Lung Disease in the South African Mining Industry. Research and Policy Implementation', Journal of Public Health Policy 32(Supp1), pp. 65-79, DOI:10.1057/jphp.2011.25.

Nattrass, N. (1995) 'The Crisis in South African Gold Mining', World Development, 22(5), pp. 857-868, DOI:10.1016/0305-75oX(95)00007-Y.

NEDLAC Act (1994) National Development and Labour Council Act, Government Gazette 35 (G16126) (Pretoria: Government Printing Works), http://www.saflii.org/za/ legis/num_act/nedalca1994437/ (accessed on 27 June 2017).

Phakathi, S. (2012) 'Worker Agency in Colonial, Apartheid and Post-Apartheid Gold Mining Workplace Regimes', Review of African Political Economy, 39(132), pp. 279-294, DOI: https://doi.org/10.108o/03056244.2012.688806.

Pijoos, I. (2017) 'Benoni Residents Living in Fear Following Death of 14 Illegal Miners', News24, 3 March, https://www.news24.com/SouthAfrica/News/benoni-residents-living-in -fear-following-death-of-14-illegal-miners-20170307 (accessed on 25June 2017). 
PMG (Parliamentary Monitoring Group) (2010) Mining Regulatory Framework: Mining Industry Growth, Development and Employment Task Team (MIGDETT) Achievements and Challenges, report 10 May, (Cape Town: Parliamentary Monitoring Group), https://pmg.org.za/committee-meeting/116oo/ (accessed on 23 June 2017).

Reuters (2018a) 'Miners' Silicosis Lawsuit Close to Settlement-Report', Eyewitness News, 7 February, http://ewn.co.za/2018/02/o7/miners-silicosis-lawsuit-close-tosettlement-report (accessed on 10 February 2018).

Reuters (2018b) 'SA Gold Producers, Miners Reach Silicosis Settlement', IOL News, 3 May, https://www.iol.co.za/news/south-africa/sa-gold-producers-miners-reachsettlement-14762756 (accessed on 10 May 2018).

Ryan, B. (2016) 'The DMR Hits Back on Safety Stoppages', miningmx, 23 August, http:// www.miningmx.com/new/markets/27893-dmr-hits-back-mines-safety-stoppages / (accessed on 23 June 2017).

Saul, G. (1993) The Ending of an Era: Redefining South Africa's Relationship with the International Labour Organisation (Johannesburg: The South African Insitute of International Affairs, University of the Witwatersrand), https://www.africaportal.org/ documents/16o6/The_Ending_Of_An_Era.pdf (accessed on 30 January 2018).

Seekings, J. and N. Nattrass (2002) 'Class, Distribution and Redistribution in PostApartheid South Africa', Transformation, (50), pp. 1-30, DOI: https://doi.org/10.1353/ trn.2003.0014.

Stewart, P (2015) 'Accelerated mechanisation and the demise of a mass-based workforce? Platinum mines in South Africa', Review of African Political Economy, 42(246), pp. $633-642$.

Theron, J. (2005) 'Employment Is Not What It Used To Be. The Nature and Impact of Work Restructuring in South Africa', in E. Webster and K. von Holdt (eds.) Beyond the Apartheid Workplace. Studies in Transition (Scottsville: University of Kwa-Zulu Natal), pp. 293-316.

von Holdt, K. and E. Webster (2005) 'Work Restructuring and the Crisis of Social Reproduction. A Southern Perspective', in E. Webster and K. von Holdt (eds.) Beyond the Apartheid Workplace. Studies in Transition (Scottsville: University of Kwa-Zulu Natal), pp. 3-40.

Webster, E. and K. Joynt (2014) Repositioning Social Dialogue: The South African Case, Global Labour Column (Johannesburg: Corporate Strategy and Industrial Development(CSID), University of theWitwatersrand), http://www.global-labour-university .org/fileadmin/GLU_Column/papers/no_191_Joynt_Webster.pdf (accessed on 25 June 2017).

Webster, E. and D. Sikwebu (2010) 'Tripartism and Economic Reforms in South Africa and Zimbabwe', in L. Fraile (ed.) Blunting Neoliberalism: Tripartism and Economic Reforms in the Developing World (Basingstoke: Palgrave MacMillan), pp. 177-223. 
Webster, E., B. Asanda, X. Dilata, K. Joynt, K. Ngoepe and M. Tsoeu (2008) Making Visible the Invisible: Confronting South Africa's Decent Work Deficit, commissioned report of the Department of Labour of South Africa (Cape Town, Johannesburg and Pretoria: Human Sciences Research Council, Development Policy Research Unit and the Sociology of Work Unit), http://www.labour.gov.za/DOL/downloads/documents/ research-documents/webster.pdf (accessed on 8 February 2018). 